\title{
Etiologisk versus prognostisk strategi i klinisk epidemiologisk forskning
}

\author{
Mikael Abdelnoor og Irene Sandven \\ Kompetansesenter for klinisk forskning, Ullevål Universitetssykehus. 0407 Oslo
}

E-post:miab@uus.no

\begin{abstract}
SAMMENDRAG
Epidemiologisk forskning tar sikte på å beskrive helsetilstanden i en populasjon, årsak til sykdom, predikere og forebygge sykdom. Dette innebærer forskning med ulik strategisk tilnærming. Vi har to strategier, den forklarende og den pragmatiske. Begge strategier er fundamentale i klinisk forskning. Den forklarende strategi fokuserer på å forstå mekanismer i en sykelig prosess ved å peke på etiologiske eller kausale risikofaktorer. I denne strategi er det derfor assosiasjonen mellom eksponering (E) og endepunkt (D) som er hovedhypotesen. Alle andre variabler er bare interessante i den grad de påvirker denne assosiasjonen som en confounder eller effektmodifikator. Den pragmatiske strategi er orientert mot risikofaktorer som predikerer sykdom slik at profylaktiske forholdsregler kan tas. Ved denne strategi er hensikten å finne de variabler som predikerer endepunktet (D) og identifisere undergrupper av pasienter med høy risiko for et endepunkt. Begge strategier krever at våre resultater kan generaliseres. Dette innebærer at utvalgspopulasjonen må være godt definert og selektert i den forklarende strategi, og nær den kliniske virkelighet $\mathrm{i}$ den pragmatiske strategi. Begge strategier har forskjellig utforming i observasjonelle studier og eksperimentell klinisk forskning. Strategi er et viktig konsept i klinisk epidemiologisk forskning, fordi det har betydning for valg av utgangspopulasjon, analysemetoder og konklusjoner.
\end{abstract}

\section{INTRODUKSJON}

Valg av strategi er avgjørende ved all klinisk forskning. Oftest står valget mellom en forklarende eller etiologisk problemstilling og en pragmatisk eller prognostisk problemstilling. Valg av strategi har betydning for hvilken utgangspopulasjon (source population) en velger, utforming av studien og valg av analysemetoder. Disse synspunktene ble introdusert av D.Schwartz allerede i $1971(1,2)$ og videreutviklet de senere år av Poccok (3) og Hennekens (4).

\section{STRATEGI}

\section{Strategi ved kliniske observasjonsstudier}

Den forklarende (eksplanatoriske) strategi er basis for etiologisk forskning. Aktuelle eksempler på dette fra vårt eget miljø er bruk av østrogen og økt risiko for hjerteinfarkt hos kvinner (5), kolesterolnivå og hjertesykdom, effekt av IMA-graft ved koronar bypasskirurgi, gunstig effekt av aspirin som profylakse mot å utvikle hjerteinfarkt, redusert mortalitet og reinfarkt hos overlevende etter hjerteinfarkt ved warfarinbehandling (1). Hovedhypotesen er at det finnes en assosiasjon mellom en eksponering (E), som $i$ våre eksempler er østrogen, kolesterolnivå, IMA-graft, aspirin og warfarin, og et endepunkt (D), som kan være hjerteinfarkt, mortalitet, hjertesykdom.

Ved denne strategien er det assosiasjonen mellom eksponering (E) og endepunkt (D) som er av betydning. Alle andre variabler er bare av interesse $i$ den grad de påvirker og forandrer assosiasjonen mellom $\mathrm{E}$ og D, uttrykt som Relativ Risk (RR) eller Odds Ratio
(OR). En variabel som påvirker denne assosiasjonen kan være en confounder eller en effektmodifikator ( $F i-$ gur 1). Å påvise en confounder eller effektmodifikator er viktige elementer i denne strategien.

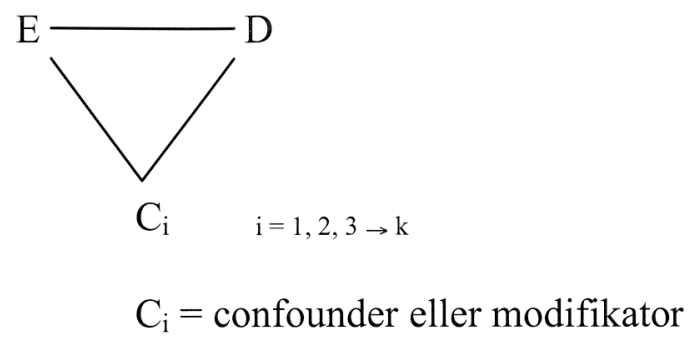

Figur 1. Eksplanatorisk strategi.

En confounder gir en assosiasjon uten kausal sammenheng. For eksempel er det en kjent assosiasjon mellom bruk av p-piller og hjerteinfarkt hos kvinner. Kvinnens alder er assosiert både med bruk av p-piller og risikoen for å utvikle hjerteinfarkt. Med andre ord er alder her en confounder assosiert både med eksponering (p-pille bruk) og endepunkt (hjerteinfarkt), men uten å ligge i den kausale vei mellom dem. For å identifisere variabler som ligger i den kausale vei mellom eksponering og endepunkt, trengs det inngående kunnskap om biologiske og fysiologiske mekanismer. Low density lipoprotein (LDL) er et eksempel på en variabel som ligger i den kausale vei mellom en fettholdig kost (E) og risiko for å utvikle hjertesykdom (D), fordi vi fra fysiologien vet at slikt kosthold er assosiert med 
LDL. Tar vi et eksempel fra obstetrikken hvor vi studerer sammenhengen mellom maternell røking (E) og barnedødelighet (D), er fødselsvekt en variabel som ligger i den kausale vei mellom E og D fordi vi vet at røking påvirker intrauterin vekst som igjen øker risikoen for prematur fødsel. Variabler som ligger i den kausale vei mellom eksponering og endepunkt kan ikke kontrolleres for som en confounder.

Effektmodifikasjon, eller interaksjon, er til stede når assosiasjonen mellom eksponering (E) og endepunkt (D) varierer i forskjellig grad på forskjellig nivå av en tredje faktor (effektmodifikator). Dersom vi gjør en stratifisert analyse og finner at effekten av assosiasjonen mellom eksponering og endepunkt er signifikant høyere på et nivå (stratum) enn et annet, kan dette skyldes en effektmodifikasjon (interaksjon). For eksempel er diabetes mellitus en effektmodifkator mellom behandling med warfarin versus aspirin og endepunktet for pasienter som overlever et akutt hjerteinfarkt. Hos diabetikere ble det påvist en bedre effekt av aspirin sammenlignet med warfarin, mens det hos ikke-diabetikere ble påvist en gunstig effekt av warfarin sammenlignet med aspirin (6). I noen tilfeller kan en variabel være både en confounder og en effektmodifikator. Det finnes statistiske metoder for å sannsynliggjøre hvorvidt en variabel er en effektmodifikator. Slike metoder tester homogeniteten av effekten mellom strata. Å påvise en effektmodifikator har stor betydning i klinisk epidemiologisk forskning.

Den pragmatiske eller prognostiske strategi tar sikte på å finne de variabler som predikerer et endepunkt (D) og finne undergrupper av pasienter med høy risiko for et endepunkt, slik at det er mulig å ta profylaktiske forholdsregler (Figur 2). Dette var hensikten med Framingham-studien og Oslo-undersøkelsen, hvor målet var å finne prediktorer for hjerteinfarkt og hjertesykdom hos middelaldrende menn.

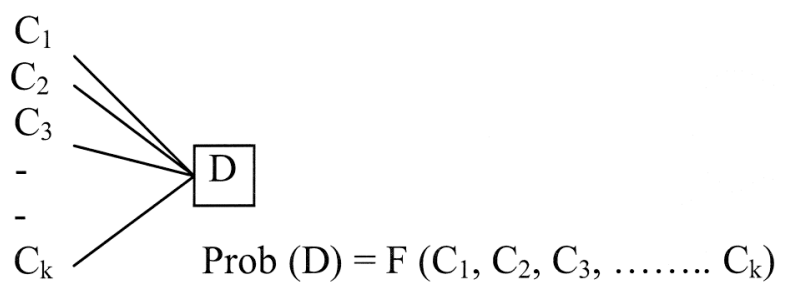

Prob (D) = sannsynlighet for utfall (D)

Figur 2. Pragmatisk strategi.

Denne strategi er svært viktig i kliniske undersøkelser, som for eksempel før hjertekirurgi å kunne identifisere pasienter som kan komme til å utvikle sirkulasjonssvikt med behov for assistert sirkulasjon med aorta-ballong-pumpe (7). Ved en slik strategi er alle variabler av interesse for å lage en indeks, en score eller beregne sannsynligheten for å utvikle de forskjel- lige komplikasjoner og hendelser (events). For eksempel utviklet D'Agostino og medarbeidere empirisk en logistisk funksjon for å predikere akutt hjertesykdom (ACHD) (8). Deretter testet de om modellen var anvendelig for leger i akuttmottak til diagnostisk bruk hos pasienter med mistenkt ACHD, og til å vurdere behovet for innleggelse og overvåking i hjerteavdeling. Denne testen var basert på ni kliniske, anamnestiske og elektrokardiografiske variabler. I praksis førte studien til bedre diagnostikk, reduksjon i antall unødvendige innleggelser på hjerteovervåkning og færre falske positive diagnoser.

Ved denne strategi er vi ikke interessert i analyse av kovariater som confoundere og effektmodifikatorer for de ulike endepunktene. Hensikten er ved multivariat analyse å bestemme de prediktive verdier for de forskjellige endepunktene så presist som mulig. En "goodness of fit" analyse av data er av stor betydning.

\section{Strategi ved eksperimentell klinisk forskning}

Ved eksperimentell klinisk forskning har betegnelsene eksplanatorisk og pragmatisk strategi en annen betydning. Ved forklarende (eksplanatorisk) strategi, som også betegnes som "on-treatment" eller effektivitetsstrategi, er tilnærmingen gjort med henblikk på effekten av en potensiell behandling under optimale betingelser. Ved analysene, utviklet av Schwarz et al. (1), utelukkes individer som viser dårlig compliance. Det vil si individer som viser dårlig evne til å holde seg til det behandlingsopplegget som er gitt, skifter behandlingsgruppe underveis og de som av forskjellige andre grunner trekkes ut av studien. Ved pragmatisk strategi, eller "intention to treat" strategi, er vi interessert $\mathrm{i}$ den aktuelle effekt av behandlingen i klinisk praksis med individer som viser dårlig compliance, forandrer behandling på grunn av utilfredsstillende effekt, bivirkninger eller tapes av syne. Ved en pragmatisk tilnærming beholdes alle individer i den opprinnelige gruppen uten hensyn til compliance, overflytting mellom gruppene eller eksklusjon fra studien.

\section{STRATEGI OG PROTOKOLLER}

Strategi må velges allerede i den første planleggingsfasen av studien, fordi det har direkte betydning for valg av populasjon (eligible population) og unders $\varnothing-$ kelsesmetoder.

Etiologisk eller eksplanatorisk tilnoerming krever at våre resultater kan generaliseres og verifiseres $i$ forskjellige populasjoner. Undersøkeren bruker sofistikerte biologiske metoder, og må ha plausible hypoteser for kausalitet basert på biologi, genetikk og immunologi, samt epidemiologiske holdepunkter fra litteraturen. Den utvalgte populasjonen må være godt definert og selektert med henblikk på å bedømme effektivitet under optimale forhold.

Pragmatisk tilncerming krever at den utvalgte (eligible) populasjon er nær den kliniske virkelighet slik at 
resultatene kan overføres til hele populasjonen. Hensikten er å forutsi utfallet. Denne metoden har vært mye brukt i store epidemiologiske studier ved å bestemme de prediktive verdier av forskjellige variabler for utvikling av hjertesykdom (angina pectoris, hjerteinfarkt og plutselig død). Sannsynligheten for å få sykdommen i fremtiden kan estimeres når eksponering for ulike risikofaktorer er kjent. Dette krever longitudinelle kohortstudier. Hvis vi for eksempel betrakter The Framingham Heart Study, har Kanell et al. (9) estimert sannsynligheten for at en person utvikler hjertesykdom i løpet av de neste åtte år etter undersøkelsen. Ut fra resultatene fra denne studien kan vi predikere hjertesykdom hos en bestemt person ved å sette fingeren på aktuelle risikofaktorer hos denne personen. La oss si at vi ønsker å anslå risikoen hos en 50 år gammel mann som røker, har et serum-kolesterol på $280 \mathrm{mg} / 100 \mathrm{ml}$, et systolisk blodtrykk på $180 \mathrm{mmHg}$, en venstre ventrikkelhypertrofi og normalt blodsukker. Sammenlignet med menn på samme alder er den generelle risikoen for å utvikle hjertesykdom 115/1000 (Tabell 1). Tabell 2 viser koeffisienten beregnet ut fra Framingham-kohorten ved hjelp av en logistisk modell. For å predikere sannsynligheten for hjertesykdom de neste åtte år hos en frisk mann, multipliserer vi verdien av risikofaktorene med koeffisienten og summerer produktene. I vårt eksempel blir dette:

$$
\begin{aligned}
\mathrm{C}= & {[(50)(0,3743307)]-\left[(50)^{2}(0,0021165)\right]+} \\
& {[(2,80)(0,0258102)]+[(180)(0,0150953]+} \\
& {[(1)(0,5583013)]+[(1)(1,0529656)]+} \\
& {[(0)(0,6020336)]+[(2,80)(50)(0,0003619)]-} \\
& 19,7705560=-1,8877
\end{aligned}
$$

Sannsynligheten for å utvikle hjertesykdom P er gitt ved:

$$
\mathrm{P}=1 /\left(1+\mathrm{e}^{-\mathrm{c}}\right)=1 /\left(1+\mathrm{e}^{1,8877}\right)=1 /(1+6,6042)=0,1315
$$

Mannen i vårt eksempel har da en risiko på 13\%, eller 1 over 8 , for å utvikle hjertesykdom i løpet av de kommende åtte år.

Vanligvis kan slik prediktering ikke skille fullstendig mellom lavrisiko- og høyrisikopasienter. Det er en overgangssone der den positive prediktive verdi varierer avhengig av hvilke grenseverdier en setter for variabelen som måler patologi og sykdommens prevalens, for eksempel ST-senking på 1 eller $2 \mathrm{~mm}$ som kriterium for positiv test ved belastnings-EKG. Den prognostiske kvaliteten avhenger også av hvilke faktorer som velges ved oppbygging av en risikoscore. Vanligvis er faktorer med kausal betydning av størst interesse. Etiologiske faktorer av betydning for utvikling av "low-output-syndrome" (LOS) etter åpen hjertekirurgi var nedsatt hjertefunksjon ved NYHAklassifisering, tidligere klaffeoperasjon, samtidig andre kirurgiske inngrep og endokardittisk etiologi. Endokardittisk etiologi hadde kausal betydning for opptreden av myokardial dysfunksjon.

$\AA$ finne den prediktive verdi av en variabel er av interesse i klinisk praksis dersom det gjør det mulig å ta forholdsregler. Sivertsen et al. (10) har vist at en av de viktigste risikofaktorer for hjerteinfarkt etter hjertekirurgi var lang avklemmingstid av aorta, med en dose-respons-effekt som tyder på kausal sammenheng. Dette funn indikerer at ved å korte ned på tiden aorta avklemmes, kan forekomsten av hjerteinfarkt reduseres etter hjertekirurgi.

Et annet problem ved den pragmatiske tilnærming er en naturlig variabilitet i prediksjonsverdi på grunn av at populasjonen forandres i løpet av undersøkelsen. Populasjonen av hjerteopererte pasienter ved Ullevål sykehus i tidsrommet 1988 til 1990 hadde en annen risikoprofil når det gjelder morbiditet (Low Output Syndrome) og tidlig død enn pasienter som ble operert tidlig på 1970-tallet. Pragmatisk strategi gjør det nødvendig å ta hensyn til hva resultatene skal brukes til når en velger utgangspopulasjon (source population). Vi er også nødt til å bruke undersøkelsesmetoder som kan overføres til den aktuelle populasjon (target population) i den kliniske situasjonen.

Både den etiologiske og pragmatiske strategi er fundamentale i klinisk forskning. Den første fokuserer på å forstå mekanismene $\mathrm{i}$ en sykelig prosess ved å peke på etiologiske eller kausale risikofaktorer. Den andre er orientert mot risikofaktorer som predikerer endepunktene og som kan føre til preventive forholdsregler og tiltak.

Tabell 1. Sannsynligheten for å utvikle kardiovaskulær sykdom de kommende åtte år, etter alder og kjønn.

\begin{tabular}{ccc}
\hline \multicolumn{3}{c}{ Insidensen av kardiovaskulær sykdom / 1000} \\
\hline Alder & Menn & Kvinner \\
\hline 35 & 18 & 5 \\
40 & 41 & 12 \\
45 & 75 & 25 \\
50 & 115 & 48 \\
55 & 159 & 80 \\
60 & 193 & 119 \\
65 & 212 & 160 \\
70 & 229 & 199 \\
\hline
\end{tabular}

Tabell 2. Koeffisienten i den logistiske modellen for å estimere risiko for hjertesykdom.

\begin{tabular}{lr}
\hline Variabel & \multicolumn{1}{c}{ Mann } \\
\hline Alder (i år) & 0,3743307 \\
Alder x alder & $-0,0021165$ \\
S-Cholesterol (mg/ml) & 0,0258102 \\
Systolisk blodtrykk (mmHg) & 0,0156953 \\
Røkevaner* & 0,5583013 \\
Venstre ventrikkel hypertrofi på EKG* & 1,0529656 \\
Glucosetoleranse* & 0,6020336 \\
Cholesterol x alder & $-0,0003619$ \\
Konstant & $-19,7709560$ \\
\hline
\end{tabular}

$*$ ja $=1$, nei $=0$ 


\section{REFERANSER}

1. Rumenau-Rouquet C, Schwartz D. Methodes en Epidemiologie. Flamarion-Medecines. Paris: 1971.

2. Schwartz D. Risque et facteurs de risk en epidemiologie et sante publique. Le Concours Medical 1981; 103-6: 745-751.

3. Poccok S. Clinical Trials, 1992

4. Hennekens C, Burning J. Epidemiology in Medicine. Little Brown, 1989.

5. Shapiro S, Slone D, Rosenberg I. Oral-contraceptive use in relation to myocardial infarction. Lancet 1979; 313: 743-746.

6. Abdelnoor M, Hurlen M, Smith P, Arnesen H. Diabetes mellitus is an effect modifier between warfarin versus aspirin treatment, and the end point in patients with acute myocardial infarction (The WARIS II Randomized Clinical Trial). Norsk Epidemiologi 2003; 13: 44.

7. Abdelnoor M, Hall KV, Nitter-Hauge, et al. Facteurs de risque de morbidité et de mortalité dans le traitement chirurgical de la maladie valvulaire aortique chronique. Rev Epidém Santé Pub 1988; 36: 89-98.

8. D'Agostino RB, Pozen MW. The logistic function as an aid in the detection of acute coronary disease in emergency patients (a case study). Stat Med 1982; 1 (1): 41-48.

9. Kannel WB, McGee D, Gordon T. A general cardiovascular risk profile. The Framingham Study. Am $J$ Cardiol 1976; 38: 45-51.

10. Sivertsen E, Abdelnoor M, Fjeld NB, Platou E. Heart surgery at Ullevål Hospital 1988-1990. Ullevål Hospital, 1994. 